\title{
LACK OF ANNUAL PERIODICITY IN CAMBIAL PRODUCTION OF PHLOEM IN TREES FROM MEDITERRANEAN AREAS
}

\author{
Jožica Gričar ${ }^{1, *}$, Peter Prislan ${ }^{1}$, Martin De Luis ${ }^{2}$, Klemen Novak ${ }^{2,4}$, \\ Luis Alberto Longares ${ }^{2}$, Edurne Martinez del Castillo ${ }^{2}$, and Katarina Čufar ${ }^{3}$ \\ ${ }^{1}$ Slovenian Forestry Institute, Vecna pot 2, 1000 Ljubljana, Slovenia \\ 2Universidad de Zaragoza - IUCA, Departamento de Geografía y O.T., C/Pedro Cerbuna 12, \\ 50009 Zaragoza, Spain \\ ${ }^{3}$ University of Ljubljana, Biotechnical Faculty, Department of Wood Science and Technology, \\ Jamnikarjeva 101, 1000 Ljubljana, Slovenia \\ ${ }^{4}$ Universidad de Alicante, Departamento de Ecología, Carretera S. Vicente del Raspeig s/n, \\ 03080 San Vicente del Raspeig, Alicante, Spain \\ *Corresponding author; e-mail: jozica.gricar@gozdis.si
}

\begin{abstract}
Annual periodicity of cambium production of xylem and phloem cells has rarely been compared in trees from different environments. We compared the structure of cambium and the youngest xylem and phloem increments in four tree species, Fagus sylvatica, Picea abies, Pinus sylvestris and Pinus halepensis, from nine temperate and Mediterranean sites in Slovenia and Spain. In Picea abies, Pinus sylvestris and Fagus sylvatica from temperate locations in Slovenia, xylem and phloem growth ring boundaries could be identified. In Fagus sylvatica growing at two elevations on Moncayo mountain, Spain, phloem increment consisted of only early phloem. In Pinus sylvestris from the same two sites, growth ring boundaries were not as clear as in temperate Slovenian sites. In some cases we could identify phloem growth ring boundaries but in others it was very doubtful, which could be explained by collapse of the outermost early phloem sieve cells. In Pinus halepensis from all sites, we could only distinguish between collapsed and non-collapsed phloem, while phloem rings could not be identified. Widths of the youngest phloem and xylem annual increments could only be compared when phloem increments could be clearly defined, as with Picea abies, Fagus sylvatica and Pinus sylvestris from temperate sites. The visibility of the growth ring boundary in phloem was not related to the width of annual radial growth. The correlation between xylem and phloem ring widths was high, but moderate between the number of dormant cambial cells and xylem ring and phloem ring widths. Based on the structure of the youngest phloem increments, we concluded that there is no typical annual periodicity in cambial production of phloem cells in trees from certain Mediterranean sites. This may be due to continuous yearlong cell production and the absence of true cambium dormancy, at least on the phloem side, under mild winter conditions.
\end{abstract}

Keywords: European beech (Fagus sylvatica), Norway spruce (Picea abies), Scots pine (Pinus sylvestris), Aleppo pine (Pinus halepensis), cambium, Mediterranean $\&$ temperate climate, growth ring boundary. 


\section{INTRODUCTION}

Cambial activity is regulated by a complex of endogenous and environmental factors (Savidge 1996). In well-adapted woody plants, the annual course of cambial activity normally coincides with the climatic rhythm, which is conservative and may serve as an indicator of the geographical origin of species (Waisel \& Fahn 1965). Cambial rhythm (i.e., seasonal periods of its activity and dormancy) in plants from temperate and Mediterranean climatic regions differs; the cambium of trees from temperate regions exhibits clear dormancy during the winter period (e.g. Fromm 2013; Prislan et al. 2013a). In contrast, cambial activity in plants from Mediterranean regions does not always have a regular dormancy period (Cherubini et al. 2003; De Luis et al. 2011a, b). Although phenological behaviour may reflect the way in which plants exploit favourable climatic conditions, cambial activity is considered to be one of the best parameters for investigating the adaptation of plants to their environment (Liphschitz \& Lev-Yadun 1986). Comparison of the patterns of cambial rhythm of activity and the structure of xylem and phloem increments can thus show the degree of adaptation of tree species to their habitat. In well-adapted woody plants, the annual rhythm of cambial activity parallels or overlaps the climatic rhythm (Waisel \& Fahn 1965).

Formation of xylem and phloem tissues is initiated in the vascular cambium. The dynamics of seasonal xylem and phloem formation are not synchronous, thus capturing different environmental information (Gričar et al.2015a). In addition to environmental factors, the structure and width of phloem and xylem increments, as well as their interrelationship, depend also on plant species, plant age, plant vigour, plant vitality, etc. The number of dormant cambial cells reflects the initial capacity of the cambium to accomplish cell division (Gričar et al.2009, 2014a). Cambial cell production in terms of number of cells produced is normally greater on the xylem than on the phloem side. However, in the case of reduced radial growth, a tree's preference is for phloem formation, leading to a progressively smaller ratio between xylem and phloem widths (Bauch 1986; Larson 1994). Since phloem sieve elements function for only one to two growing seasons, tree survival depends on the yearly formation of new phloem to maintain and extend the translocation pathways for photosynthates and biomolecules (Evert 2006; Taiz \& Zeiger 2006). Missing or discontinuous rings in xylem have been regularly reported, particularly in trees from extreme environments (Novak et al.2011, 2016; Wilmking et al. 2012; De Micco et al. 2016), or in trees with reduced vitality (Torelli et al. 1999), whereas phloem is formed every year, even if very narrow.

Wood anatomical traits have been widely used to investigate and compare tree performance in different environments (e.g., Baas \& Schweingruber 1987; Lachenbruch \& McCulloh 2014; Beeckman 2016). However, not much is known about the intraannual plasticity of secondary growth of tree species from different environments, particularly in terms of the cambial rhythm of xylem and phloem cell production. It was demonstrated for Fagus sylvatica and Picea abies that the seasonal dynamics of phloem formation showed lower variability than xylem formation at the same site (Prislan et al. 2013b; Gričar et al. 2014b). Although phloem development was partly affected by local environmental conditions, the timing of phloem formation and its structure 
only moderately varied among years (Prislan et al. 2013b; Gričar et al. 2014b). At locations that are favourable for the growth of these two species, variation in the structure of xylem and phloem increments was mainly observed at the site level rather than on a temporal scale. In addition, xylem and phloem tissues formed in the first part of the growing season seemed to be more stable in structure, which indicates predominantly endogenous control of their formation. Less variability in structure also suggests that early wood and phloem components are crucial for long-term tree performance (Gričar et al. 2014b, 2015b).

The annual periodicity of the cambium in trees from different environments has rarely been compared, especially focusing on xylem-phloem relationships. In the current study, we analysed and compared the structure and width of cambium and latest formed xylem and phloem annual increments in order to estimate the annual cambial periodicity in four tree species, Fagus sylvatica, Picea abies, Pinus sylvestris and Pinus halepensis, from temperate and Mediterranean climatic environments. The term cambium is defined here as a tissue comprising meristematic cells organized in radial files, which give rise to secondary xylem and phloem (Larson 1994). According to the multi-seriate concept of cambium structure, it consists of both cambial initial cells and xylem and phloem mother cells (Plomion et al. 2001). Since the initial and mother cells are cytologically identical (except for a small difference in length) it is not possible to determine them on transverse sections at the cellular level (Mellerowicz et al. 2001), the term cambial cells will be used hereafter to denote both initial and mother cells.

\section{MATERIAL AND METHODS}

\section{Study site characteristics}

The study was carried out at nine forest sites with different altitudes and latitudes; four in Slovenia and five in Spain. Detailed descriptions of the study site characteristics, climatic data and descriptions of tree characteristics are presented in Table 1. The sites were divided into two groups; Mediterranean ones with mild winters and, in some cases, a low amount of annual precipitation, and temperate ones characterized by cold winters with temperatures regularly dropping below zero. Mean annual temperature and mean annual amount of precipitation for the sampled period at each study site are presented in Table 1. In Slovenia, daily weather data for the sites Ljubljana (LJ) and nearby Panška reka (PA) were obtained from the Ljubljana weather station (LjubljanaBežigrad $46^{\circ} 03^{\prime} \mathrm{N}, 14^{\circ} 30^{\prime} \mathrm{E}, 299 \mathrm{~m}$ a.s.1.) of the Environmental Agency of the Republic of Slovenia. At Menina planina (ME), a Davis ${ }^{\circledR}$ weather station was installed to measure air temperature and precipitation at hourly intervals. It was placed in the vicinity of the test trees in a small forest clearing, approximately two metres above the ground. For the Spanish sites Guardamar, Maigmo and Jarafuel, weather data for the studied periods were obtained from the closest grid point of the CRU 3.10 dataset of $0.5^{\circ}$ grid resolutions (Harris et al . 2014) and for Moncayo from two Campbell Scientific weather stations placed nearby the sampling sites, which measured air temperature and precipitation every fifteen minutes. 


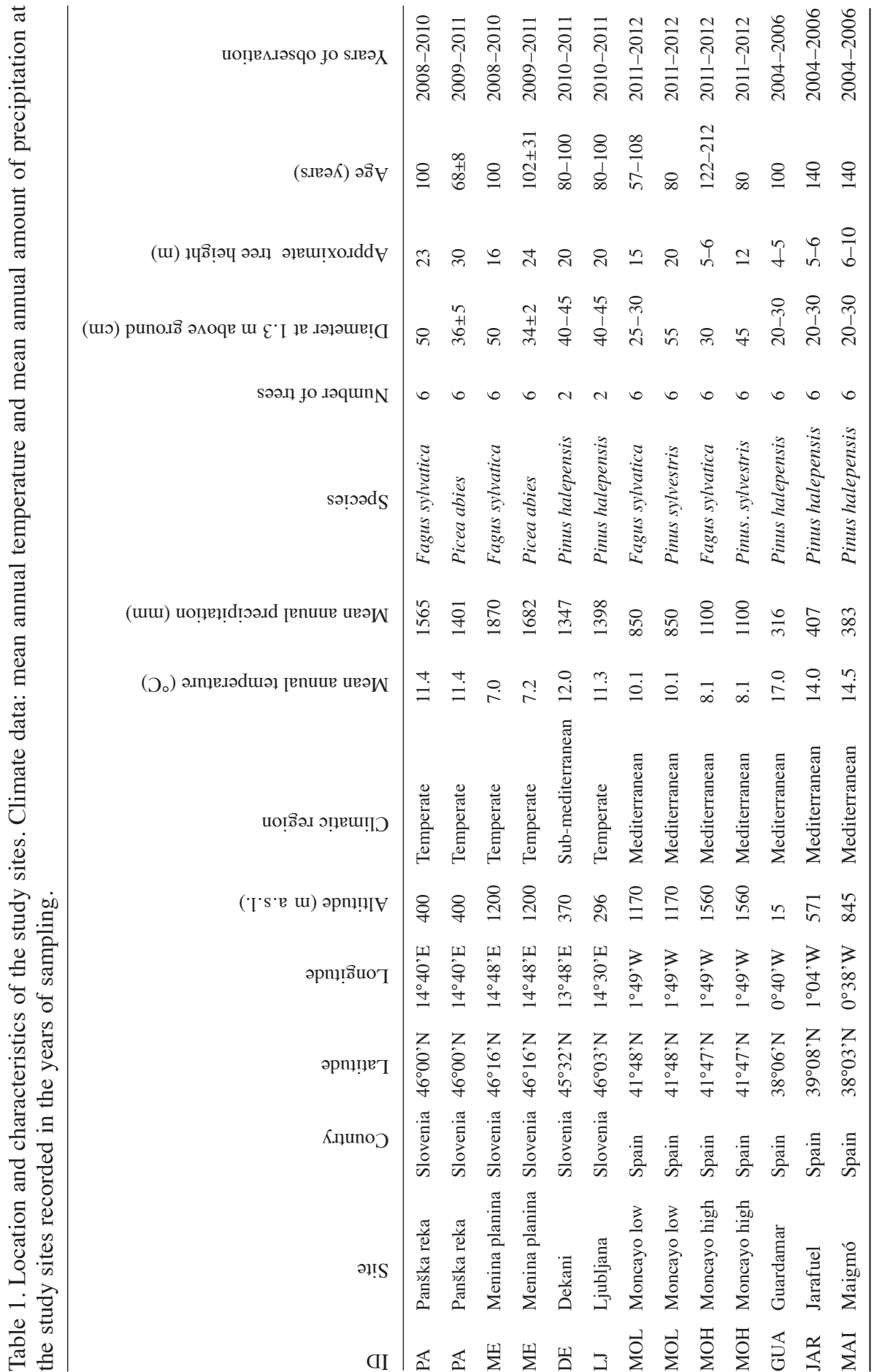




\section{Sample collection and preparation}

At each location, samples containing inner phloem, cambium and outer xylem were taken at $1.3 \mathrm{~m}$ above the ground at the end of the growing season from each tree, when the cambium was dormant and the latest formed xylem and phloem growth rings were fully developed. In general, 3 or 4 samples were taken from each tree at the end of each growing season. The material was immediately fixed in formalin-ethanol-acetic acid solution (FAA), dehydrated in a graded series of ethanol solutions $(30 \%, 50 \%$ and $70 \%$ ) after one week and finally embedded in paraffin (Paraplast plus, ROTH, Karlsruhe, Germany) (Gričar 2007). Permanent cross sections of 10-13 $\mu$ m thickness were prepared for light microscopy on a Leica RM 2245 rotary microtome (Leica Microsystems, Wetzlar, Germany) using disposable Feather N35H blades (Osaka, Japan). The sections were transferred to object glass and stained with a water mixture of safranin (Merck, Darmstadt, Germany) (0.04\%) and Astra blue (Sigma-Aldrich, Steinheim, Germany) (0.15\%) (Van der Werf et al. 2007) and embedded in Euparal (Waldeck, Münster, Germany). A Nikon Eclipse 800 light microscope (Tokyo, Japan) and the Nikon NIS-Elements Basis Research v.2.3 image analysis system (Tokyo, Japan) were used for observations and evaluation of the tissue.

\section{Anatomical analyses of cambium, phloem and xylem, and data processing}

We adopted Barnett's (1971) criteria for defining the annual growth cycle in the phloem. It is based on three phloem-anatomical traits: 1) visibility of annual growth rings in the phloem; 2) distribution of parenchyma cells and 3) cyclic changes in the morphology of sieve cells, similar as in xylem. If the axial parenchyma cells were arranged in tangential rows and periodic changes in the anatomy of sieve cells occurred, we assumed that an annual cycle of phloem growth existed (Fig. 1a). If these markers were absent and phloem growth ring boundaries were difficult to distinguish, we assumed that a cyclic growth pattern did not occur in the phloem (Fig. 1b).

We examined the widths of dormant cambium (CC) and the adjacent youngest xylem (XR) and phloem (PR) annual growth rings for three radial files in each histological section. Xylem and phloem increments were measured immediately after the cessation of cambial activity and cell differentiation processes. This was important because early phloem sieve cells already start to collapse in the autumn of the current growing season, which we tried to avoid. We calculated the ratios between the xylem and phloem increments in order to estimate and compare the cambial cell production on the xylem and phloem sides. Annual increments were expressed as measured widths. The observed tissues were defined as follows. 1) Dormant cambial cells were identified by their narrow radial dimensions and thin, unlignified primary cell walls that stained blue. 2) Xylem cells were distinguished by thick, lignified cell walls that stained red, whereas lumina were empty. 3) The phloem sieve cells/tubes were defined by thin, unlignified, blue-stained cell walls of round to irregular shape. The cell walls of sieve cells/tubes were slightly thicker than those of the cambium. The radial dimensions of the early phloem sieve cells/tubes were greater than in the late phloem. The axial parenchyma was distinguished from the sieve cells/tubes by the stained content in the lumen. 
Pearson's Product Moment Correlation Coefficient was used to evaluate the strength of the association between xylem and phloem ring widths, between the number of dormant cambial cells and xylem ring widths, and between the number of dormant cambial cells and phloem ring widths.

\section{RESULTS}

\section{Intra-annual structure of phloem increments}

In the samples taken from Pinus sylvestris, Picea abies and Fagus sylvatica trees from temperate locations in Slovenia, we were able to recognize growth ring boundaries of the youngest phloem increments in all cases (Fig. 1). Phloem growth rings consisted of early phloem, late phloem and tangentially arranged axial phloem parenchyma cells that normally delineate early and late phloem components. Early phloem sieve cells of the conifers generally had wider radial dimensions than late phloem sieve cells. Typical of Pinaceae is an additional wall layer in the sieve cells, which is considered to be secondary wall (Abbe \& Crafts 1939). The tangential walls of the first sieve cells of the early phloem adjacent to the previous year's crushed sieve cells were slightly convex, which facilitated determination of the growth ring boundaries (Gričar \& Čufar 2008).

In Fagus sylvatica, the non-collapsed phloem was composed of sieve tubes, companion cells and parenchyma cells (axial and ray parenchyma) but it did not contain phloem fibres. The sieve tubes of early phloem in Fagus sylvatica are characterized by about two times larger lumen than those of late phloem (Prislan et al. 2012). In F. sylvatica growing at two different elevations in Moncayo, Spain, phloem increment was composed of only an early phloem part (Fig. 1). The late phloem part was lacking. Since variations in the radial dimension of (early phloem) sieve tubes were less distinct, the boundaries were relatively difficult to recognize. In Pinus sylvestris from the same two sites, growth ring boundaries were also less distinct than at the temperate Slovenian sites. At both elevations, we were able to ascertain the boundaries in some cases although it was very doubtful in others. This could be explained by the collapse of the outermost early phloem sieve cells. The collapse might have started relatively soon, before the end of the growing season, since the phloem increments were fairly wide.

In Pinus halepensis from all sites, we were only able to distinguish between collapsed and non-collapsed secondary phloem, while phloem rings could not be recognized (Fig. 1). Variations in the radial dimensions of sieve cells did not show any clear cyclic pattern, resulting in alternate tangentially arranged layers of early and late phloem components. In P. halepensis, therefore, we could not demarcate early and late phloem

Figure 1. Structure of phloem in four species from different sites: (a) Picea abies (Panška reka), (b) Pinus halepensis (Jarafuel), (c) Pinus sylvestris (Ljubljana), (d) P. sylvestris (Moncayo high), (e) Fagus sylvatica (Panška reka) and (f) F. sylvatica (Moncayo high). Cambial cells (CC), non-collapsed phloem (NCP), collapsed phloem (CP), phloem ring (PR), early phloem (EP), late phloem (LP). - Scale bars $100 \mu \mathrm{m}$. For abbreviations of sites see Table 1. 

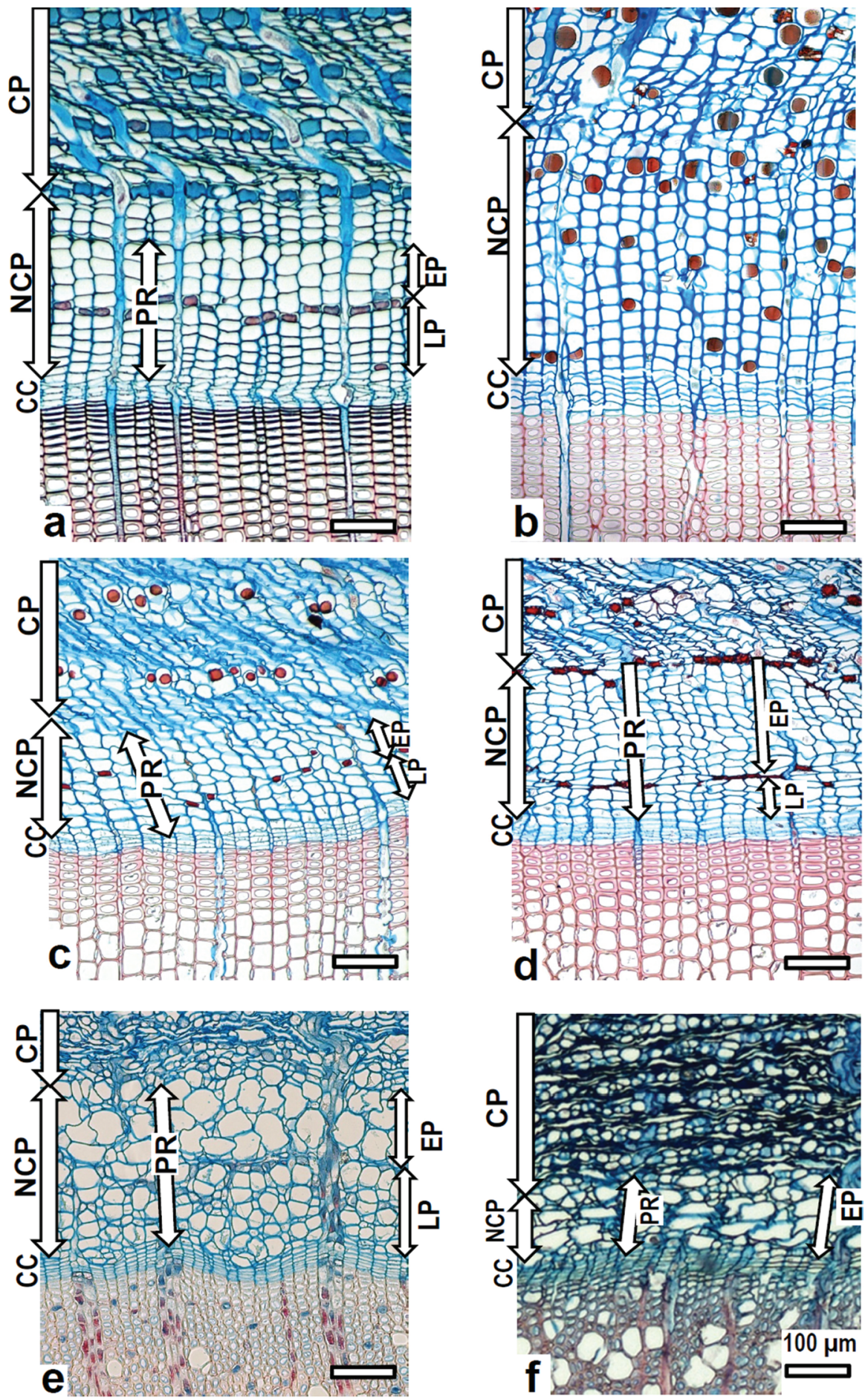
since the axial parenchyma cells were randomly distributed within the phloem and a gradual reduction in the radial dimension of sieve cells from early to late phloem was not evident. In contrast, in P. sylvestris from the sub-Mediterranean site in Slovenia (DE), a tangential band of axial parenchyma cells could be observed at the border between early and late phloem (Fig. 1).

\section{Phloem vs xylem increments}

The widths of the youngest phloem and xylem annual increments could only be compared when phloem increments could be clearly defined (Fig. 1). This was the case for Picea abies, Fagus sylvatica and Pinus sylvestris from temperate sites (Table 2). In trees with indistinguishable growth ring boundaries in the phloem, i.e., Pinus halepensis and partly $P$. sylvestris from the Mediterranean sites, such a comparison was not possible. In trees with clear ring boundaries, the increments were wider in xylem than in phloem in all cases, indicating more frequent cell divisions on the xylem side.

The visibility of the growth ring boundary in the phloem was not related to the width of the annual radial growth. This can be clearly seen from the great variations in xylem ring widths of the trees from both the temperate sites $(0.6-2.6 \mathrm{~mm})$ and the Mediterranean sites $(0.5-1.7 \mathrm{~mm})$. The variation in the phloem increment widths of the trees from temperate sites was slightly lower; the widths ranged from 90 to $300 \mu \mathrm{m}$. In narrower phloem increments, the growth ring was mainly composed of early phloem (Table 2).

Table 2. Average phloem and xylem ring widths and number of dormant cambial cells of the studied trees at the selected sites.

Phloem and xylem ring widths are calculated for the years of observation. Phloem ring widths were not possible to measure in trees with indistinguishable growth ring boundaries in the phloem. Bold text: trees from temperate locations; regular text: trees from Mediterranean sites.

For abbreviations of sites see Table 1 .

\begin{tabular}{llcccc}
\hline Site & Tree species & $\begin{array}{c}\text { Phloem ring } \\
\text { width }(\mu \mathrm{m})\end{array}$ & $\begin{array}{c}\text { Xylem ring } \\
\text { width }(\mu \mathrm{m})\end{array}$ & $\begin{array}{c}\text { Ratio xylem: } \\
\text { phloem }\end{array}$ & $\begin{array}{c}\text { No. of dormant } \\
\text { cambium cells }\end{array}$ \\
\hline PA & Fagus sylvatica & $\mathbf{1 9 0} \pm \mathbf{9 2}$ & $\mathbf{2 3 3 4} \pm \mathbf{1 1 8 2}$ & $\mathbf{1 2 . 3}$ & $\mathbf{4 . 7} \pm \mathbf{1 . 9}$ \\
PA & Picea abies & $\mathbf{2 9 4} \pm \mathbf{4 7}$ & $\mathbf{2 5 8 2} \pm \mathbf{1 3 6 5}$ & $\mathbf{8 . 8}$ & $\mathbf{6 . 7} \pm \mathbf{0 . 8}$ \\
ME & Fagus sylvatica & $\mathbf{1 8 0} \pm \mathbf{2 2}$ & $\mathbf{1 1 9 6} \pm \mathbf{5 6 8}$ & $\mathbf{6 . 7}$ & $\mathbf{5 . 3} \pm \mathbf{0 . 5}$ \\
ME & Picea abies & $\mathbf{2 2 8} \pm \mathbf{3 9}$ & $\mathbf{1 3 1 2} \pm \mathbf{6 5 4}$ & $\mathbf{5 . 8}$ & $\mathbf{6 . 6} \pm \mathbf{0 . 6}$ \\
DE & Pinus halepensis & - & $1703 \pm 645$ & - & $7.4 \pm 0.9$ \\
LJ & Pinus sylvestris & $\mathbf{1 9 4} \pm \mathbf{1 3}$ & $\mathbf{7 4 0} \pm \mathbf{4 5 0}$ & $\mathbf{3 . 8}$ & $\mathbf{4 . 9} \pm \mathbf{0 . 9}$ \\
MOL & Fagus sylvatica & $120 \pm 31$ & $573 \pm 473$ & 4.8 & $4.3 \pm 0.6$ \\
MOL & Pinus sylvestris & - & $888 \pm 572$ & - & $5.7 \pm 1.3$ \\
MOH & Fagus sylvatica & $95 \pm 28$ & $555 \pm 333$ & 5.9 & $4.8 \pm 0.6$ \\
MOH & Pinus sylvestris & - & $945 \pm 343$ & - & $5.9 \pm 1.0$ \\
GUA & Pinus halepensis & - & $1361 \pm 834$ & - & $6.4 \pm 1.3$ \\
JAR & Pinus halepensis & - & $868 \pm 512$ & - & $5.2 \pm 1.2$ \\
MAI & Pinus halepensis & - & $489 \pm 212$ & - & $5.8 \pm 0.9$ \\
\hline & & & & &
\end{tabular}



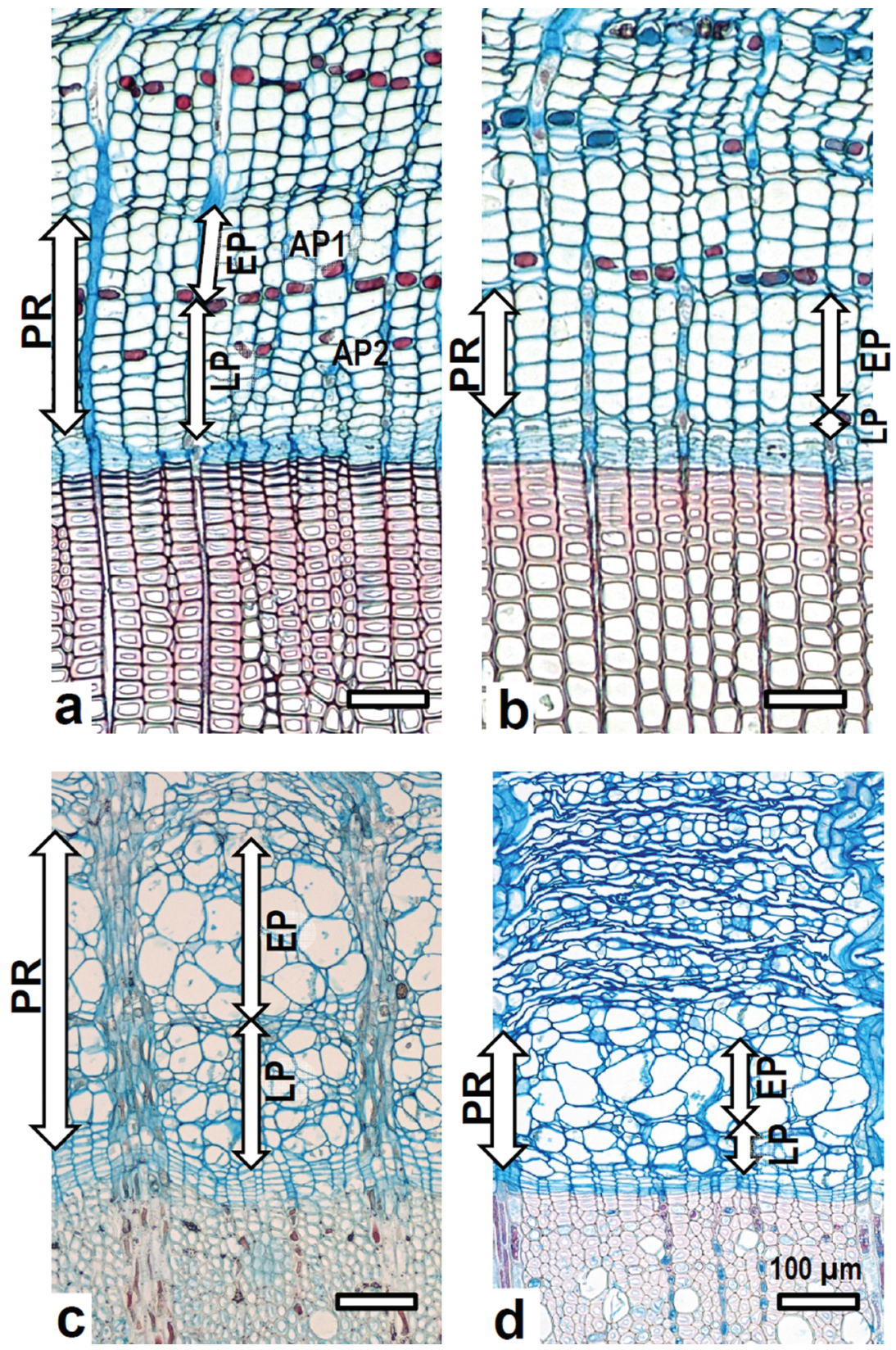

Figure 2. Different structure and width of phloem increments (PR) in Picea abies (a, b) and Fagus sylvatica (c, d): (a) wide PR containing up to 10 layers of late phloem cells (LP) with additional discontinuous tangential layer of axial parenchyma cells (AP); (b) narrow phloem ring composed of mainly early phloem sieve cells (EP); tangential band of AP is lacking; (c) wide PR composed of almost equally wide EP and LP components; (d) narrow PR with very narrow proportion of LP. - Scale bars $100 \mu \mathrm{m}$. 
In Picea abies, for example, wider phloem increments contained 3-5 layers of early phloem sieve cells, a continuous tangential band of axial parenchyma cells and up to 10 layers of late phloem cells, with an additional discontinuous tangential layer of axial parenchyma cells, which is common for wider rings (Fig. 2a). Narrow phloem rings were composed of mainly early phloem sieve cells and the tangential band of axial parenchyma was lacking (Fig. 2b). Similarly in Fagus sylvatica, wide phloem rings were composed of almost equally wide early and late phloem parts, whereas narrow phloem rings consisted almost exclusively of early phloem (Fig. 2c, d). Annual xylem and phloem increments of $F$. sylvatica from the Spanish sites were markedly narrower than those in trees from the Slovenian sites (Fig. 3).
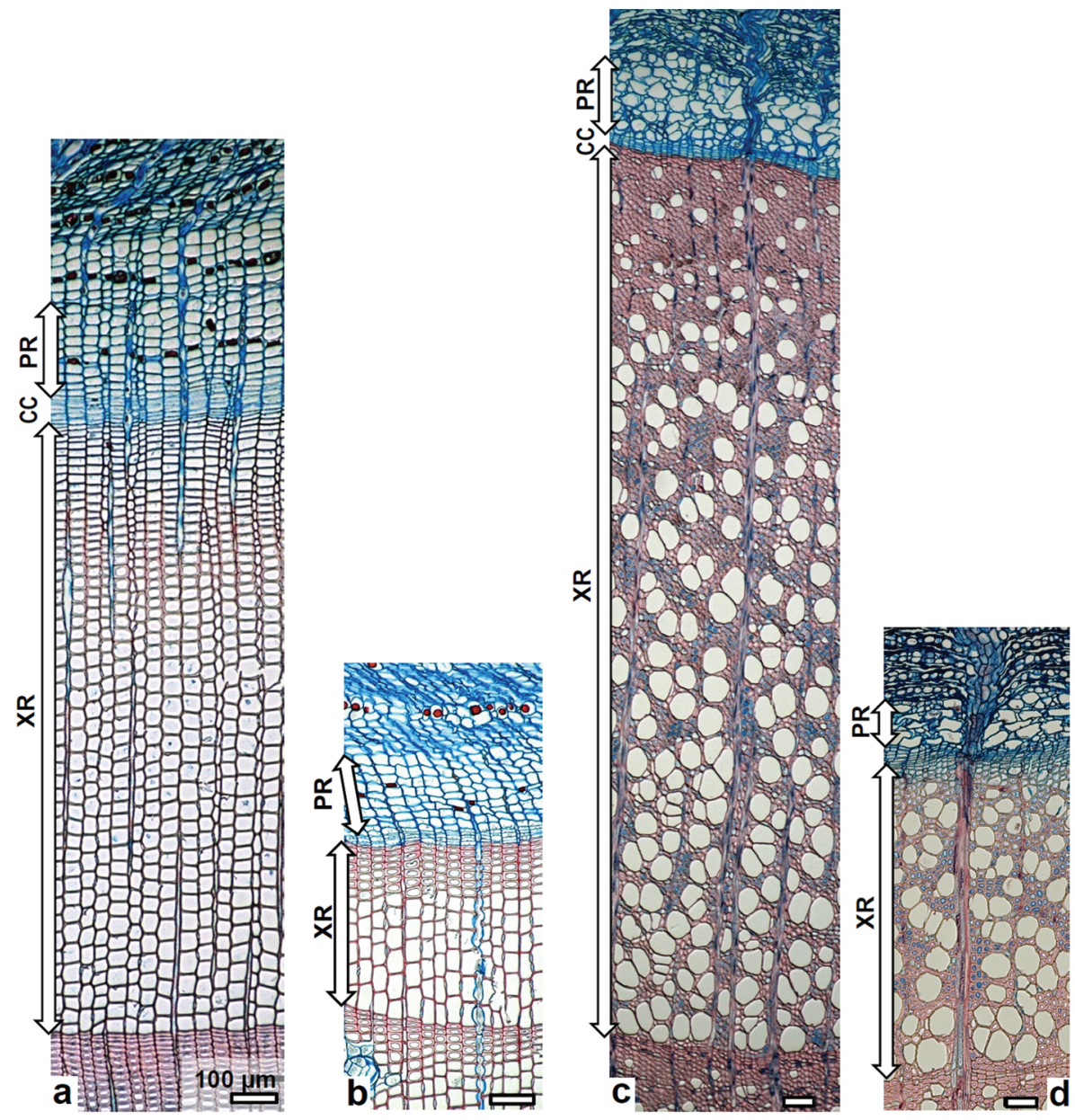

Figure 3. Xylem (XR) and phloem rings (PR) in three species from different sites: (a) Picea abies (Panška reka), (b) Pinus sylvestris (LJ), (c) Fagus sylvatica (Panška reka) and (d) F. sylvatica (Moncayo high). Phloem ring (PR), xylem ring (XR). - Scale bars $100 \mu \mathrm{m}$. For abbreviations of sites see Table 1. 
The number of dormant cambial cells was also variable among the trees. We observed a strong correlation between xylem and phloem ring widths $(r=0.78)$ and between the number of dormant cambial cells and phloem ring widths $(r=0.84)$, moderate between the number of dormant cambial cells and xylem ring widths $(r=0.58)$ and weak between the number of dormant cambial cells and the ratio of xylem and phloem ring widths $(r=0.11)$.

\section{DISCUSSION}

\section{Structure of phloem increments}

The structure of bark is complex and varies considerably among different tree species in terms of its cellular and chemical composition, as well as physical properties (e.g., Srivastava 1964). In the samples of trees from temperate and Mediterranean highaltitude locations, we were able to recognize growth ring boundaries of the youngest phloem increments. Width of the phloem increments varied among the trees. Narrow phloem rings were composed of mainly early phloem parts, which is in agreement with our earlier presumption that the structure of early phloem is more stable and less dependent on ring width than the late phloem (Gričar et al. 2009, 2015a; Prislan et al. 2012). Consequently, in the case of reduced radial growth, the proportion of the early growth component of the phloem increment increases. The collapse of early phloem cells has started relatively soon, before the end of the growing season. Since the phloem increments were fairly wide; there was therefore a sufficient amount of recently formed tissue available for basipetal translocation of the photosynthates and biomolecules. It has previously been noted that early phloem sieve tubes in Fagus sylvatica already slowly began to collapse at the end of the current growing season, when the xylem growth rings were fully formed (Prislan et al.2013b; Gričar et al.2015b). In the collapsed phloem, sieve cells were crushed because of the cessation of their conducting function, which was accompanied by an accumulation of callose on the sieve plates, followed by loss of cell contents and collapse of the cells (Trockenbrodt 1990). As a result of the age-related secondary changes in older phloem tissue, an enlargement of parenchyma cells, formation of sclereids and distortion of rays occur; the older phloem growth rings consequently become more and more indistinguishable with increasing distance from the cambium (Prislan et al. 2012; Gričar et al. 2015b). In Pinus halepensis from the Mediterranean (Spain) and sub-Mediterranean (Slovenia) regions, phloem rings could not be recognized. Variations in the radial dimensions of sieve cells did not show any clear cyclic pattern, resulting in alternate tangentially arranged layers of axial parenchyma and early and late phloem components. We were only able to distinguish between collapsed and non-collapsed secondary phloem. Thus, typical annual periodicity in the development of phloem cells did not exist in those trees.

\section{Phloem vs xylem vs cambium}

The number of dormant cambial cells was also variable among the trees. We found the strongest correlation between the number of dormant cambial cells and phloem ring widths and moderate between the number of dormant cambial cells and xylem ring 
widths. Although the number of cells in the dormant cambium depends on tree species, tree age and tree vitality (e.g., Golinowski 1971; Larson 1994), it also reflects cambial cell production capacity (Gričar et al.2009, 2014a). This measure can only be used to estimate and compare cell production capacity of the dormant cambium for trees from similar environments (temperate, boreal etc.). The widths of the youngest phloem and xylem annual increments could only be compared when phloem increments could be clearly defined. In trees from Mediterranean areas, cambium may not be in the dormant state in some years. Consequently, only the relationship between the number of cambial cells and xylem increment can be assessed in these areas. The increments were wider in xylem than in phloem in all cases, indicating more frequent cell divisions on the xylem side. This is common for trees growing under normal conditions (Panshin \& De Zeeuw 1980; Larson 1994; Kozlowski \& Pallardy 1997). Annual xylem and phloem increments of Fagus sylvatica from the Spanish sites were markedly narrower than those in trees from the Slovenian sites, which could be explained by the considerably lower amount of precipitation at the Spanish sites.

\section{Annual rhythm of the cambium}

The cambium of trees from temperate areas normally exhibits clear dormancy during the winter period and xylem growth follows a unimodal pattern. In contrast, conifers from Mediterranean climates need to be plastic enough to cope with contrasting rainfall patterns (Camarero et al.2010; De Luis et al. 2011a, b, 2013). Cambial reactivation on the xylem side benefits from both autumn rainfall and sporadic late-summer rainfall events, resulting in the formation of intra-annual density fluctuations, which characterize the tree-rings of most conifers from Mediterranean environments (Campelo et al. 2007, 2015; Novak et al.2013a, b, 2016; De Micco et al.2016). In addition, although cambial cell production of xylem cells stops for a short time in winter, the differentiation process of xylem cells may continue at a very slow rate during this period (Barnett 1971). Barnett (1971) concluded that variation in cambial seasonality and cell differentiation is a species and site specific phenomenon. Thus, for Pinus halepensis, a bimodal annual xylem growth pattern is typical, characterized by spring and autumn cambial reactivation (De Luis et al. 2007; Camarero et al. 2010), unlike the unimodal pattern, with one spring peak of cambial activity, in Pinus sylvestris, which performs as a temperate conifer even when growing under Mediterranean conditions. In P. sylvestris, photoperiod and temperature changes appear to trigger the seasonal dynamics of xylem growth (Camarero et al. 2010). The structure of phloem and xylem increments of Fagus sylvatica from Slovenian and Spanish sites reflect the annual periodicity of cambial cell production and unimodal pattern of their development. However, the growing season is presumably considerably shorter and/or the rate of cell production reduced at the latter site, as concluded from the markedly narrower annual increments. Nevertheless, the differences in the timing of cambial activity and cell differentiation on the xylem and phloem sides are also subject to hormonal regulation (Aloni 2013).

Based on the structure of the youngest phloem increments, we concluded that typical annual periodicity in the development of phloem cells does not exist in trees from 
Mediterranean sites; with the exception of Mediterranean sites on Moncayo mountain. This might be explained by continuous cell production throughout the year and thus the absence of true dormancy of the cambium, at least on the phloem side, in trees from environments with mild winter conditions, as already proposed by Barnett (1971). He further inferred that genetic factors, which also greatly control dormancy and are selected for a tree's native environment, would prevail over environmental factors (e.g., day-length or temperature) in mild winter climatic conditions that are favourable for cambial activity. However, in the case of harsh climatic conditions compared to those of the tree's native environment, climatic factors may override the genetic ones (Barnett 1971). In evergreen species, the cambial rhythm is preserved even when plants grow under climatic conditions that differ from those of their natural habitat. In deciduous trees, in contrast, a rapid adaptation to new environmental conditions has been often observed, e.g., on transfer of species from the northern to the southern hemisphere (Waisel \& Fahn 1965).

There are many morphological and physiological strategies of woody species to survive in different environments (Lachenbruch \& McCulloh 2014). Xylem tissues, which perform hydraulic and mechanical functions in a tree, are known to respond adaptively to biotic and abiotic factors. Wood-morphological traits influence the hydraulic or mechanical properties, which, in combination with environmental factors, influence the performance of the plant. At the tissue and cell levels, wood anatomical traits have largely been studied in this respect (e.g., Baas 1983; Baas \& Schweingruber 1987), whereas the potential of phloem anatomical traits still needs to be exploited. In the phloem, not only the morphology of conducting cells is important; the amount and function of storage tissues (i.e., parenchyma cells) has important implications for whole-plant transport processes and resource partitioning as well (Spicer 2014).

\section{CONCLUSIONS}

Cambial rhythm, as evaluated by the amount of xylem and phloem cells produced in trees from Mediterranean regions, is not synchronous, as is typical of temperate trees, but is considerably less uniform. The radial growth of certain tree species from mild climates does not exhibit a distinct annual cycle, suggesting that variation in cambial seasonality and cell differentiation is a species and site specific phenomenon, as already suggested by Barnett (1971). Not much is known about the intra-annual dynamics of phloem growth of Mediterranean trees, because studying phloem is a challenging task due to age related changes in older tissue and to wound reactions after sampling. Consequently, phloem formation patterns in trees lacking annual phloem rings remain poorly understood and their relation to ecophysiological processes in Mediterranean environments is still unclear. Although only a limited number of species and locations could be included in our study, it hopefully illustrates the complexity of cambium rhythm on xylem and phloem sides. This study might stimulate similar studies aimed at providing additional information on intra-annual radial growth patterns and dormancy in plants from contrasting environments. 


\section{ACKNOWLEDGEMENTS}

The authors gratefully acknowledge the help of Luka Krže, Maks Merela and Marko Željko for their help in the field and in the laboratory. The authors thank Martin Cregeen for checking the English text. The authors thank the reviewers for their valuable comments and suggestions to improve the quality of the paper. This work was supported by the Slovenian Research Agency (ARRS), young researchers' program (Peter Prislan) and programs P4-0015 and P4-0107, ARRS and the Ministry of Agriculture, Forestry and Food, project V4-1419, by the FP7 Capacities project EUFORINNO (REGPOT no. 315982), and by the Spanish Science and Innovation Ministry (MICINN), program ELENA (CGL2012-31668 and CGL2015-69985-R). The cooperation among the international partners was supported by COST Action FP1106, STReESS.

\section{REFERENCES}

Abbe LB \& Crafts AS. 1939. Phloem of white pine and other coniferous species. Bot. Gaz. 100: 695-722.

Aloni R. 2013. Role of hormones in controlling vascular differentiation and the mechanism of lateral root initiation. Planta 238: 819-830.

Baas P. 1983. Some ecological trends in vessel characters. IAWA Bull. n.s. 4: 141-159.

Baas P \& Schweingruber FH. 1987. Ecological trends in the wood anatomy of trees, shrubs and climbers from Europe. IAWA Bull. n.s. 8: 245-274.

Barnett J. 1971. Winter activity in the cambium of Pinus radiata. NZ J1. For. Res. 1: 208-222.

Bauch J. 1986. Characteristics and response of wood in declining trees from forests affected by pollution. IAWA Bull. n.s. 7: 269-276.

Beeckman H. 2016. Wood anatomy and trait-based ecology. IAWA J. 37: 127-151.

Camarero JJ, Olano JM \& Parras A. 2010. Plastic bimodal xylogenesis in conifers from continental Mediterranean climates. New Phytol. 185: 471-480.

Campelo F, Nabais C, Freitas H \& Gutiérrez E. 2007. Climatic significance of tree-ring width and intra-annual density fluctuations in Pinus pinea from a dry Mediterranean area in Portugal. Ann. For. Sci. 64: 229-238.

Campelo F, Vieira J, Battipaglia G, De Luis M, Nabais C, Freitas H \& Cherubini P. 2015. Which matters most for the formation of intra-annual density fluctuations in Pinus pinaster: age or size? Trees 29: 237-245.

Cherubini P, Gartner BL, Tognetti R, Bräker OU, Schoch W \& Innes JL. 2003. Identification, measurement and interpretation of tree rings in woody species from Mediterranean climates. Biol. Rev. 78: 119-148.

De Luis M, Čufar K, Di Filippo A, Novak K, Papadopoulos A, Piovesan G, Rathgeber CBK, Raventós J, Saz MA \& Smith KT. 2013. Plasticity in dendroclimatic response across the distribution range of Aleppo pine. PLoS ONE 8 (12): e83550.

De Luis M, Gričar J, Čufar K \& Raventós J. 2007. Seasonal dynamics of wood formation in Pinus halepensis from dry and semi-arid ecosystems in Spain. IAWA J. 28: 389-404.

De Luis M, Novak K, Raventós J, Gričar J, Prislan P \& Čufar K. 2011a. Climate factors promoting intra-annual density fluctuations in Aleppo pine (Pinus halepensis) from semiarid sites. Dendrochronologia 29: 163-169.

De Luis M, Novak K, Raventós J, Gričar J, Prislan P \& Čufar K. 2011b. Cambial activity, wood formation and sapling survival of Pinus halepensis exposed to different irrigation regimes. Forest Ecol. Manag. 262: 1630-1638.

De Micco V, Campelo F, De Luis M, Bräuning A, Grabner M, Battipaglia G \& Cherubini P. 2016. Intra-annual density fluctuations in tree rings: how, when, where and why? IAWA J. 37: $232-259$. 
Evert RF. 2006. Esau's Plant anatomy meristems, cells, and tissues of the plant body: their structure, function, and development. Wiley-Interscience, Hoboken, New Jersey.

Fromm J. 2013. Cellular aspects of wood formation. Springer, Heidelberg, New York, London. Golinowski WO. 1971. The anatomical structure of the common fir (Abies alba Mill.) bark. 1. Development of bark tissues. Acta Soc. Bot. Pol. 40: 149-181.

Gričar J. 2007. Xylo- and phloemogenesis in silver fir (Abies alba Mill.) and Norway spruce (Picea abies (L.) Karst.). Slovenian Forestry Institute, Ljubljana.

Gričar J \& Čufar K. 2008. Seasonal dynamics of phloem and xylem formation in silver fir and Norway spruce as affected by drought. Russ. J. Plant Physiol. 55: 538-543.

Gričar J, Jagodic Š \& Prislan P. 2015b. Structure and subsequent seasonal changes in the bark of sessile oak (Quercus petraea). Trees 29: 747-757.

Gričar J, Jagodic Š, Šefc B, Trajković J \& Eler K. 2014a. Can the structure of dormant cambium and the widths of phloem and xylem increments be used as indicators for tree vitality? Eur. J. For. Res. 133: 551-562.

Gričar J, Krže L \& Čufar K. 2009. Number of cells in xylem, phloem and dormant cambium in silver fir (Abies alba), in trees of different vitality. IAWA J. 30: 121-133.

Gričar J, Prislan P, De Luis M, Gryc V, Hacurova J, Vavrčik H \& Čufar K. 2015a. Plasticity in variation of xylem and phloem cell characteristics of Norway spruce under different local conditions. Front. Plant. Sci. 6: 730.

Gričar J, Prislan P, Gryc V, Vavrčík H, De Luis M \& Čufar K. 2014b. Plastic and locally adapted phenology in cambial seasonality and production of xylem and phloem cells in Picea abies from temperate environments. Tree Physiol. 34: 869-881.

Harris I, Jones P, Osborn T \& Lister D. 2014. Updated high-resolution grids of monthly climatic observations - the CRU TS3. 10 Dataset. Int. J. Climatol. 34: 623-642.

Kozlowski TT \& Pallardy SG. 1997. Growth control in woody plants. Academic Press, London.

Lachenbruch B \& McCulloh KA. 2014. Traits, properties, and performance: how woody plants combine hydraulic and mechanical functions in a cell, tissue, or whole plant. New Phytol. 204: 747-764.

Larson PR. 1994. The vascular cambium: development and structure. Springer, Berlin.

Liphschitz N \& Lev-Yadun S. 1986. Cambial activity of evergreen and seasonal dimorphics around the Mediterranean. IAWA J. 7: 145-153.

Mellerowicz EJ, Baucher M, Sundberg B \& Boerjan W. 2001. Unravelling cell wall formation in the woody dicot stem. Plant Mol. Biol. 47: 239-274.

Novak K, De Luis M, Čufar K \& Raventós J. 2011. Frequency and variability of missing tree rings along the stems of Pinus halepensis and Pinus pinea from a semiarid site in SE Spain. J. Arid Environ. 75: 494-498.

Novak K, De Luis M, Gričar J, Prislan P, Merela M, Smith KT \& Čufar K. 2016. Missing and dark rings associated with drought in Pinus halepensis. IAWA J. 37: 260-274.

Novak K, De Luís M, Raventós J \& Čufar K. 2013a. Climatic signals in tree-ring widths and wood structure of Pinus halepensis in contrasted environmental conditions. Trees 27: 927-936.

Novak K, Sánchez MAS, Čufar K, Raventos J \& De Luis M. 2013b. Age, climate and intraannual density fluctuations in Pinus halepensis in Spain. IAWA J. 34: 459-474.

Panshin AJ \& De Zeeuw C. 1980. Textbook of wood technology. McGraw-Hill, New York.

Plomion C, LeProvost G \& Stokes A. 2001. Wood formation in trees. Plant Physiol. 127: $1513-1523$.

Prislan P, Čufar K, Koch G, Schmitt U \& Gričar J. 2013a. Review of cellular and subcellular changes in the cambium. IAWA J. 34: 391-407. 
Prislan P, Gričar J, De Luis M, Smith KT \& Čufar K. 2013b. Phenological variation in xylem and phloem formation in Fagus sylvatica from two contrasting sites. Agr. Forest. Meteorol. 180: 142-151.

Prislan P, Koch G, Schmitt U, Gričar J \& Čufar K. 2012. Cellular and topochemical characteristics of secondary changes in bark tissues of beech (Fagus sylvatica). Holzforschung 66: $131-138$.

Savidge RA. 1996. Xylogenesis, genetic and environmental regulation - a review. IAWA J. 17: 269-310.

Spicer R. 2014. Symplasmic networks in secondary vascular tissues: parenchyma distribution and activity supporting long-distance transport. J. Exp. Bot. 65: 1829-1848.

Srivastava LM. 1964. Anatomy, chemistry and physiology of bark. Intern. Rev. Forestry Research 1: 203-277.

Taiz L \& Zeiger E. 2006. Plant physiology. Sinauer Associates, Sunderland, Massachusetts.

Torelli N, Shortle WC, Čufar K, Ferlin F \& Smith KT. 1999. Detecting changes in tree health and productivity of silver fir in Slovenia. Eur. J. Forest. Pathol. 29: 189-197.

Trockenbrodt M. 1990. Survey and discussion of the terminology used in bark anatomy. IAWA Bull. n.s. 11: 141-166

Van der Werf GW, Sass-Klaassen U \& Mohren GMJ. 2007. The impact of the 2003 summer drought on the intra-annual growth pattern of beech (Fagus sylvatica L.) and oak (Quercus robur L.) on a dry site in the Netherlands. Dendrochronologia 25: 103-112.

Waisel Y \& Fahn A. 1965. The effects of environment on wood formation and cambial activity in Robinia pseudacacia L. New Phytol. 64: 436-436.

Wilmking M, Hallinger M, Van Bogaert R, Kyncl T, Babst F, Hahne W, Juday G, De Luis M, Novak K \& Völlm C. 2012. Continuously missing outer rings in woody plants at their distributional margins. Dendrochronologia 30: 213-222.

Accepted: 22 February 2016 